DOI. 10.22219/fths.v4i1.15826

Received: 26 Februari 2021

Accepted: 11 April 2021

Available online: 20 April 2021

\title{
Study Pembuatan Edible Film Gel Okra \\ (Abelmoschus esculentus L.) dengan Penambahan Pati Singkong
}

Siti Mukaromatul Muslimah¹, Warkoyo ${ }^{*}$, Sri Winarsih ${ }^{3}$

${ }^{1}$ Prodi Teknologi Pangan, Fakultas Pertanian Peternakan, Universitas Muhammadiyah Malang, Malang, Indonesia

*Corrresponding author email: warkoyo@umm.ac.id

\begin{abstract}
Edible film is an organic material packaging that has plastic-like properties but is biodegradable. The components of the edible film include hydrocolloids. Okra gel is a long chain hydrocoloid polysaccharide with a high molecular weight and a constituent protein containing both hydrophilic and hydrophobic substances. The hydrophilic characteristics are used to improve the physical properties of solubility. Meanwhile, hydrophobic characteristics are used to improve barrier properties (WVTR). Okra (Abelmoschus esculentus L.) is one of the cultivated plants that is currently underutilized by the community but has benefits and high nutritional content. The addition of cassava starch aims to increase the strength of the edible film. The purpose of this study was to determine the use of okra gel proportion and cassava starch concentration in making edible films which can produce edible film characteristics that meet the standards.This study used a factorial randomized block design (RBD). The first factor is the ratio of okra gel and distilled water $(1: 3 ; 1: 1 ; 3: 1,1: 0)$. The second factor is the concentration of cassava starch $(2.5 \%$ and $5 \%(\mathrm{w} / \mathrm{V}))$. The parameters tested were yield of raw materials, thickness, solubility, transparency, tensile strength, elongation, WVTR (Water Vapor Transmison Rate) and SEM (Scanning Electron Microscopy).The results showed that there was no interaction between okra gel and cassava starch. However, the comparison of okra gel and distilled water had a significant effect on the transparency value with an average of 0.89 $1.60 \mathrm{A546} / \mathrm{mm}$. The concentration of cassava starch has a significant effect on transparency 0.89-1.60 A546/ mm, tensile strength 0.97-2.33\%. Edible film with the best treatment was obtained in G2P1 treatment (ratio of okra gel and distilled water (1:1) and $2.5 \%$ cassava starch) with a thickness of $0.08 \mathrm{~mm}$, transparency $0.58 \mathrm{~A} 546 / \mathrm{mm}$, WVTR $3.87 \mathrm{~g} / \mathrm{m} 2 / 24 \mathrm{~h}$, elongation $9.24 \%$, tensile strength $0.74 \mathrm{MPa}$ and solubility $23.56 \%$. And SEM analysis results show uneven morphology.
\end{abstract}

Key words: cassava starch, edible film, okra fruit

\section{PENDAHULUAN}

Selama kurun waktu terakhir ini bahan pengemas makanan yang terbuat dari plastik sering digunakan, sehingga para peneliti mulai banyak mengembangkan pengemas bahan organik yang memiliki sifat mirip plastik namun bersifat biodegradable yang ramah lingkungan. Salah satu alternatif kemasan ramah lingkungan (biodegradable) adalah edible film . Edible film adalah lapisan tipis yang terbuat dari bahan-bahan yang dapat dimakan yang 
berfungsi sebagai barrier terhadap transfer massa dan dapat diuraikan oleh mikroorganisme. Komponen penyusun edible film diantaranya yaitu hidrokoloid. Gel okra merupakan hidrokoloid polisakarida rantai panjang dengan berat molekul tinggi dan protein penyusun yang mengandung kedua zat yang bersifat hidrofilik dan hidrofobik. Karakteristik hidrofilik digunakan dalam memperbaiki sifat fisik kelarutan, sedangkan karakteristik hidrofobik digunakan dalam memperbaiki sifat barrier (WVTR).

Buah okra termasuk komoditi budidaya tanaman yang tumbuh di daerah tropis, yang memiliki manfaat dan kandungan gizi cukup tinggi, namun kurang dimanfaatkan oleh masyarakat. Buah okra memiliki lendir yang sangat banyak dan terdapat kandungan serat yang tinggi didalamnya. Karakteristik ini menyebabkan gel buah okra memiliki potensi sebagai agen penstabil, pengental dan agen pengikat, akan tetapi kandungan serat dalam okra tidak dapat berdiri sendiri sehingga menghasilkan edible film yang kurang kuat dan perlu ditambah dengan bahan lain untuk memberi perbaikan sifat edible film. Menurut penelitian Fitria (2018), edible film gel okra tanpa penambahan bahan pembantu dihasilkan edible yang kurang sempurna, sehingga pemanfaatan gel okra sebagai edible film masih membutuhkan bahan tambahan yang dapat membantu dalam pembentukan film yang diharapkan, karena sumber pembentuk edible film pada okra dirasa belum memenuhi standart. Penambahan pati singkong diharapkan meningkatkan padatan dalam larutan sehingga mengakibatkan ketebalan semakin meningkat dan mengakibatkan polimer-polimer yang menyusun maktriks film semakin banyak.

Pati singkong memiliki kandungan amilosa yang memberikan sifat keras sedangkan amilopektin menyebabkan sifat lengket yang memungkinkan untuk menghasilkan edible film yang lebih kuat dan fleksibel. Menurut Hidayat (2009) kestabilan edible film dipengaruhi oleh amilopektin sedangkan amilosa berpegaruh terhadap kekompakannya. Pati singkong mengandung kadar amilosa sebesar 27,38\% dan mengandung kadar amilopektin sebesar 72,62\%. Pati dengan Kadar amilosa yang tinggi menghasilkan edible film yang kuat. Berdasarkan latar belakang tersebut, maka perlu dilakukan penelitian pembuatan edible film dari gel buah okra dengan penambahan pati singkong sehingga didapatkan edible film yang memiliki sifat dan mekanik yang baik.

\section{METODE PENELITIAN}

\section{Bahan}

Bahan-bahan yang digunakan dalam penelitian ini adalah buah okra hijau yang masih segar dengan ukuran 8-12 cm, didapat dari toko swalayan Malang, gliserol, pati singkong, aquades, $\mathrm{NaOH}$ dan silica gel.

\section{Alat}


Alat-alat yang digunakan dalam penelitian ini adalah timbangan analitik digital Ohauss, spatula, talenan, pisau, blender, baskom, gelas beker, jurigen, gelas ukur, saringan, loyang, kaca, plastik PP, plastik HDPE, penggaris, gunting, thermometer, hot plate strirrer (Barnstead Thermolyne Cimarec 2), tekstur analyzer Shimadzu, Spektofotometer (Genesys20 Thermo Spectronic), magic stirrer, desikator, Oven WTC Binder 7200 Tutlingen, micrometer sekrup Mitutoyo, gelas, toples kaca, Chamber SEM (FEI type Inspect 550), cawan porselen dan karet.

\section{Pembuatan Pati Singkong}

Proses pembuatan pati singkong dimulai dari sortasi dengan tujuan memisahkan singkong yang memasuki kreteria dan layak digunakan. Kemudian penimbangan berat awal singkong. Dikupas untuk menghilangkan kulit, dan itu dicuci sampai bersih. Singkong yang sudah bersih kemudian diparut menggunakan alat pemarut tradisional. Penghalusan ini untuk mempermudah ekstraksi pati. Kemudian menambahkan aquades dengan perbandingan 5:1 dari jumlah singkong. Setelah itu disaring menggunakan saringan dengan tujuan memisahkan filtrat dengan ampas singkong. Filtrat diendapkan selama 24 jam kemudian membuang air sisa endapan. Endapan pati dicuci sebanyak 3 kali agar kotoran-kotoran yang ada di permukaan hilang. Endapan pati yang telah dicuci kemudian dikeringkan menggunakan pengering kabinet dengan suhu $60^{\circ} \mathrm{C}$ selama 12 jam. Setelah kering, endapan dihaluskan menggunakan blender dan di ayak menggunakan ukuran 80 mesh (Sutrisno, 2009).

\section{Pembuatan Edible film}

Pembuatan edible film dimulai dari persiapan bahan yaitu buah okra dan pati singkong. Tahap pertama dilakukan ekstraksi gel okra yaitu okra disortasi dengan cara memilih buah yang tidak rusak, kemudian cuci hingga bersih agar kotorannya hilang. Pebandingan okra dan air 1:6 (w/v). Okra dipotong-potong sepanjang $1 \mathrm{~cm}$. Dilakukan perendaman selama 8 jam pada suhu dingin dengan aquades sebanyak $1000 \mathrm{ml}$ dan menggunakan suhu $5^{\circ} \mathrm{C}$ yang bertujuan untuk mengeluarkan lendir dalam buah okra (Pratiwi dkk., 2016). Setelah proses perendaman dilakukan penyaringan untuk memisahkan gel dengan ampas. Selanjutnya tahap kedua adalah proses gelatinisasi pati singkong $2,5 \%, 5 \%$ (sesuai perlakuan) dengan aquades 25ml, 50ml, $75 \mathrm{ml}$ (sesuai perlakuan). Kemudian dilakukan pemanasan dengan suhu $70^{\circ} \mathrm{C}$ selama 15 menit dan ditambahkan gliserol $0,25 \mathrm{ml}$. Selanjutnya dilakukan pencampuran untuk membuat edible film yaitu proses pemanasan dengan suhu $75-80^{\circ} \mathrm{C}$ selama 15 menit. Kemudian didiamkan hingga suhu $45^{\circ} \mathrm{C}$ yang bertujuan menghilangkan gelembung. Setelah itu dicetak kemudian didiamkan selama kurang lebih 15 menit dan dilakukan pengeringan dengan suhu $75^{\circ} \mathrm{C}$ selama $12 \mathrm{jam}$. 


\section{Rancangan Penelitian}

Desain penelitian menggunakan Rancangan Acak Kelompok (RAK) faktorial terdiri dari dua faktor dengan tiga kali ulangan. Faktor pertama yaitu perbandingan gel okra dan aquades yang terdiri dari empat level ( G1= 1:3; G2= 1:1; G3= 3:1; G4= 1:0) dan faktor kedua yaitu konsentrasi pati singkong terdiri dari dua level $(\mathrm{P} 1=2,5 \%, \mathrm{P} 2=5 \%)$. Kombinasi perlakuan dari kedua faktor yaitu 8 pelakuan. Data yang diperoleh dianalisis dengan menggunakan Analysis of Variant (ANOVA) dan dilanjutkan uji banding DMRT (Duncan's Multiple Range Test) dengan taraf nyata $5 \%(\alpha=0,05)$.

\section{HASIL DAN PEMBAHASAN \\ Bahan Baku}

Pada penelitian ini dilakukan analisa bahan baku terhadap lendir buah okra dan pati singkong. Nilai rendemen yang dihasilkan dari 167 gram buah okra adalah 115,68\%. Pada Tabel 1. dapat diketahui hasil analisa rendemen gel okra dan pati singkong.

Tabel 1. Tabel Analisa Rendemen Bahan Baku

\begin{tabular}{lllll}
\hline Bahan baku & $\begin{array}{l}\text { Berat } \\
\text { Bahan }\end{array}$ & Bahan & Berat & Rendemen (\%) \\
\hline Buah Okra & $167 \mathrm{~g}$ & Gel Okra & $1530 \mathrm{~g}$ & 115,68 \\
Singkong & $8000 \mathrm{~g}$ & Pati Singkong & $900 \mathrm{~g}$ & 11,25 \\
\hline
\end{tabular}

Buah okra memiliki kandungan air yang rendah sehingga rendemen yang dihasilkan tinggi. Menurut Lim (2015) bubuk lendir okra menghasilkan kadar air sebesar 15,89\%. Sedangkan menurut penelitian fitria (2018) bubuk lendir okra menghasilkan kadar air 13,32\%. Menurut Yuniarifin dkk., (2006) Rendemen adalah perbandingan berat kering produk yang dihasilkan dengan berat bahan baku. Rendemen ekstrak dihitung berdasarkan perbandingan berat akhir (berat ekstrak yang dihasilkan) dengan berat awal (berat biomassa sel yang digunakan) dikalikan 100\% (Sani dkk., 2014).

Berdasarkan Tabel 1. Nilai rendemen pati singkong yang dihasilkan dari 8000gram ubi kayu adalah 11,25\%. Menurut penelitian Mustafa (2015) rendemen yang dihasilkan dari 2,007 gram ubi kayu pada pembuatan tepung tapioka adalah $18,744 \%$. Besarnya persen rendemen ini di pengaruhi oleh adanya proses pemblenderan pati dengan adanya pemblenderan partikel-partikel yang terbentuk akan semakin kecil dan terjadi penambahan kecepatan perputaran dari blender, sehingga pati akan lebih mudah cepat mengendap (Chairu dkk, 2008).

\section{Ketebalan}

Berdasarkan analisis ragam diketahui bahwa tidak terjadi interaksi antara perbadingan gel okra dan aquades dengan konsentrasi pati singkong terhadap 
ketebalan edible film yang dihasilkan. Demikian juga perbandingan okra dan aquades dengan konsentrasi pati singkong tidak berpengaruh nyata terhadap ketebalan edible film yang dihasilkan. Rerata nilai ketebalan edible film dapat dilihat pada Gambar 1 dan 2.

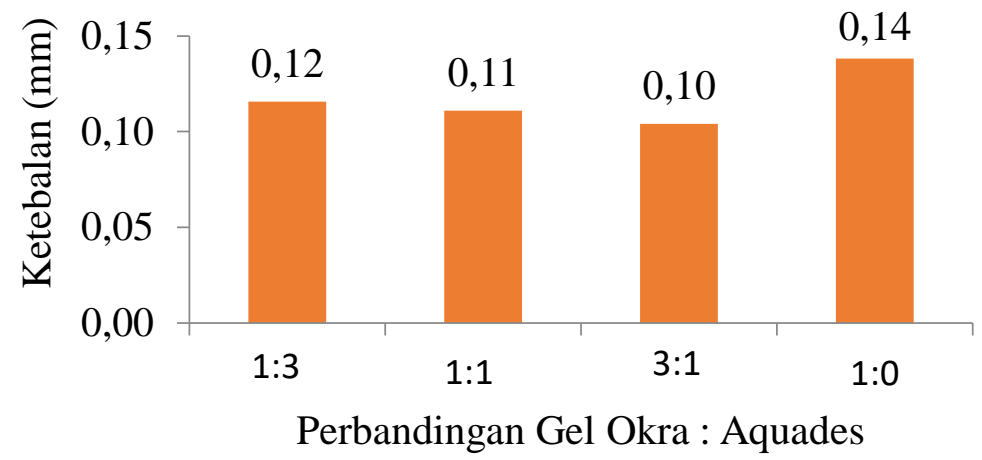

Gambar 1. Histogram Ketebalan Edible film Terhadap perbandingan Gel Okra

Berdasarkan Gambar 1. nilai rerata ketebalan edible film akibat perbedaan perbandingan gel okra dan aquades berkisar antara 0,10-0,14 mm. Berdasarkan nilai rerata ketebalan edible film penelitian ini telah memenuhi standart yaitu maksimal 0,25 mm (JIS, 1975). Nilai ketebalan edible film gel okra cenderung meningkat seiring meningkatnya gel okra yang ditambahkan, tetapi tidak sampai memberikan pengaruh yang signifikan. Hal ini dikarenakan adanya komponen pembentuk matriks film pada gel okra yang terlalu kecil sehingga penambahan gel okra yang semakin besar tidak dapat menghasilkan ketebalan edible film yang berbeda. Menurut Haris (2011) semakin tinggi konsentrasi komponen penyusun edible film maka meningkatkan total padatan sehingga meningkatkan ketebalan edible film.

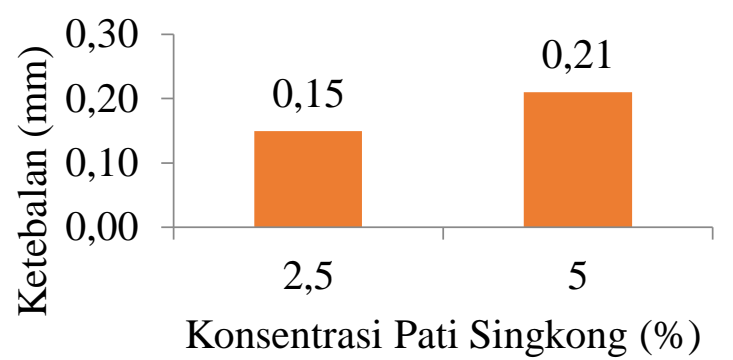

Gambar 2. Histogram Ketebalan Edible film terhadap Konsentrasi Pati Singkong

Pada Gambar 2. menunjukkan nilai rerata ketebalan edible film akibat perbedaan konsentrasi pati singkong berkisar antara 0,15-0,21 mm. Perbedaan konsentrasi pati singkong tidak berpengaruh nyata terhadap ketebalan edible film. Nilai ketebalan edible film meningkat dengan bertambahnya konsentrasi pati singkong. Hal ini dikarenakan penambahan pati singkong akan mempengaruhi ketebalan edible film, yaitu semakin tinggi konsentrasi pati yang ditambahkan akan meningkatkan total padatan dalam larutan, sehingga ketebalan film akan meningkat. Menurut pendapat Warkoyo, dkk (2014) menyatakan jumlah pati yang semakin besar, akan meningkatkan polimer penyusun matriks film, total padatan film semakin besar sehingga film yang dihasilkan akan semakin besar. 


\section{Transparansi}

Berdasarkan analisis ragam menunjukkan bahwa tidak ada interaksi antara perbandingan gel okra dan aquades dengan konsentrasi pati singkong terhadap transparansi edible film yang dihasilkan. Tetapi perbandingan gel okra dan aquades dengan konsentrasi pati singkong berpengaruh nyata terhadap transparansi edible film yang dihasilkan. Rerata nilai transparansi edible film dapat dilihat Pada Tabel 2.

Tabel 2. Rerata transparasi Edible film (A546) terhadap perlakuan Gel Okra dan aquades dengan Pati Singkong.

\begin{tabular}{ll}
\hline Perlakuan & Transparasi(A546) \\
\hline Gel okra : aquades & \\
$1: 3$ & $0,89 \mathrm{a}$ \\
$1: 1$ & $1,11 \mathrm{a}$ \\
$3: 1$ & $0,94 \mathrm{a}$ \\
$1: 0$ & $1,60 \mathrm{~b}$ \\
\hline Konsentrasi pati (\%) & \\
2,5 & $0,96 \mathrm{a}$ \\
5 & $2,14 \mathrm{~b}$ \\
\hline
\end{tabular}

Keterangan:Angka-angka yang diikuti huruf yang sama menunjukkan perbedaan yang tidak berbeda nyata (5\%) berdasarkan uji DMRT.

Berdasarkan Tabel 2. nilai rerata transparansi edible film pada penelitian ini berkisar antara 0,89-2,14 A546/mm. Perlakuan gel okra 1:0 menghasilkan transparansi tertinggi yaitu 1,60 A546/mm dibandingkan dengan perlakuan gel okra dengan $1: 3 ; 1: 1 ; 3: 1$. Transparansi cenderung meningkat dengan seiring meningkatnya gel okra yang ditambahkan. Hal ini dikarenakan penambahan gel yang semakin besar menyebabkan total padatan terlarut dalam film semakin banyak, sehingga transparansi yang dihasilkan cenderung meningkat. Menurut Bao dkk. (2009) dalam Al-Hasan dan Norziah (2012), penurunan nilai transparansi edible film ini, derajat kejernihan film akan semakin meningkat.

Transparasi edible film cenderung meningkat dengan adanya peningkatan konsentrasi pati singkong yang ditambahkan. Hal ini dikarenakan karakteristik dari pati singkong, dimana pati singkong memiliki warna putih sehingga edible film yang dihasilkan memiliki nilai transparansi yang tinggi. Menurut Krochta (1994) dalam Misnawati (2015). Perubahan warna edible film dipengaruhi oleh jumlah konsentrasi dan bahan pembentuk edible film. Menurut Kampeerappapun (2007) dalam Nawangwulan (2018). Nilai transparansi film berkaitan dengan jumlah dan ukuran partikel yang tersebar dalam matriks. Jumlah yang tinggi dan ukuran partikel yang melebihi panjang gelombang visible dapat menghalangi cahaya sehingga nilai transparansi tinggi.

\section{Kelarutan Edible film}

Berdasarkan analisis ragam diketahui bahwa tidak terjadi interaksi antara perbandingan gel okra dan aquades dengan konsentrasi pati singkong terhadap kelarutan edible film yang dihasilkan. Perbandingan gel okra dan aquades dengan konsentrasi pati singkong tidak berpengaruh nyata terhadap kelarutan 
edible film yang dihasilkan. Rerata nilai kelarutan edible film akibat perbandingan gel okra dan aquades dengan konsentrasi pati singkong dapat dilihat pada Gambar 3 dan 4.

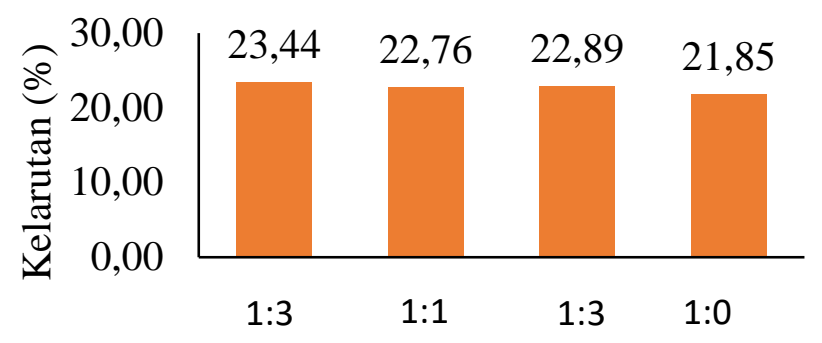

Perbandingan gel okra : aquades

Gambar 3. Histogram Kelarutan Edible film Terhadap Konsentrasi Gel Okra

Nilai rerata kelarutan edible film pada penelitian ini berkisar antara $21,85 \%-23,44 \%$. Berdasarkan Gambar 3. nilai kelarutan meningkat seiring berkurangnya proporsi gel okra yang ditambahkan. Hal ini disebabkan komponen penyusun edible film yang ditambahkan terlalu rendah sehingga kurangnya total padatan dalam film yang menghasilkan matriks film yang mudah larut. Menurut Setya (1997) dalam penelitian (Wulandari, 2015) kelarutan film dalam air disebabkan oleh konsentrasi bahan yang ditambahkan saat pembuatan film. Hasil kelarutan tertinggi mengindikasikan edible film mudah terurai dan diaplikasikan pada produk siap makan, nilai kelarutan yang tinggi menunjukkan ketahanan terhadap air lebih rendah tapi mudah larut (Fardhyanti dkk., 2015).

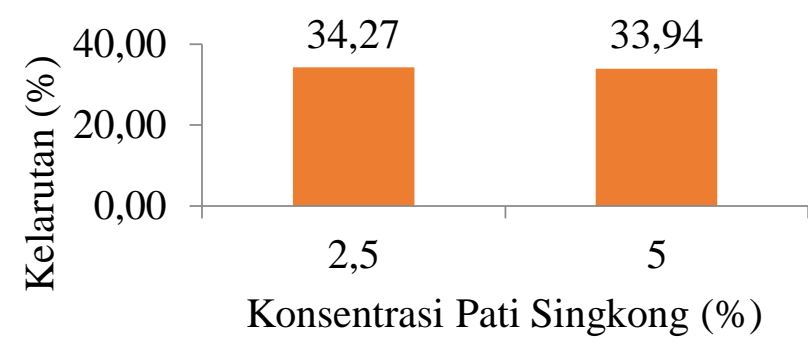

Gambar 4. Histogram Kelarutan Edible film Terhadap Konsentrasi Pati Singkong

Nilai rata-rata kelarutan edible film akibat perbedaan konsentrasi pati singkong dapat dilihat pada Gambar 4. Perbedaan konsentrasi pati singkong tidak memberikan pengaruh nyata terhadap kelarutan edible film. Rerata nilai kelarutan edible film berkisar antara 33,94\%-34,27\%. Meningkatnya konsentrasi pati singkong mengakibatkan penurunan pada nilai kelarutan edible film yang dihasilkan. Hal ini diduga penambahan konsentrasi pati singkong yang besar akan meningkatkan polimer penyusun matriks film sehingga tidak mudah larut. Penurunan kelarutan edible film cenderung terbalik dengan peningkatan konsentrasi pati singkong. Hal ini dikarenakan padatan terlarut yang berasal 
dari bahan dasar pembuatan edible film dan meningkatnya jumlah molekul dalam larutan ( Rusli dkk., 2010 ).

\section{Kuat Tarik}

Berdasarkan analisis ragam menunjukkan bahwa tidak ada interaksi antara perbandingan gel okra dan aquades dengan konsentrasi pati singkong terhadap kuat tarik. Edible film perbandingan gel okra dan aquades tidak berpengaruh nyata terhadap kuat tarik sedangkan edible film konsentrasi pati singkong berpengaruh nyata terhadap kuat tarik yang dihasilkan. Nilai rerata kuat tarik dapat dilihat pada gambar 5 dan tabel 3.

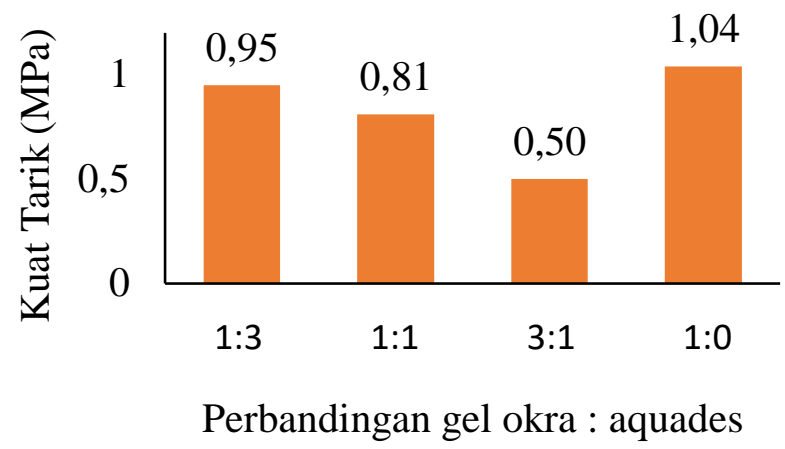

Gambar 5. Histogram Kuat Tarik Edible film terhadap proporsi Gel Okra

Berdasarkan JIS (Japanese industrial standard) (1975) dalam Nurindra dkk (2015) standar kuat tarik edible film minimal 0,392 MPa. Nilai rerata kuat tarik edible film pada penelitian ini berkisar antara $0,50 \mathrm{MPa}-1,04 \mathrm{MPa}$, dimana telah memenuhi standard JIS. Meningkatnya gel okra yang ditambahkan akan meningkatkan kuat tarik yang dihasilkan. Hal ini diduga gel okra yang merupakan komponen hidrokoloid akan meningkatkan kerapatan ruang antar molekul pada struktur film, sehingga menghasilkan edible film yang tidak rapuh. Kuat tarik merupakan salah satu sifat mekanik edible film yang penting, karena terkait dengan kemampuan film untuk melindungi produk yang dilapisinya. Tinggi rendahnya nilai kuat tarik yang dihasilkan dapat dikarenakan bahan yang terkandung dalam edible film dapat menyebabkan sulit terjadinya perpindahan posisi antar molekul (Warkoyo, dkk 2014).

Tabel 3. Rerata Kuat Tarik Edible Film (MPa) terhadap konsentrasi Pati Singkong

\begin{tabular}{cc}
\hline Konsentrasi pati singkong $(\%)$ & Kuat Tarik $(\mathrm{MPa})$ \\
\hline 2,5 & $0,97 \mathrm{a}$ \\
5 & $2,33 \mathrm{~b}$ \\
\hline
\end{tabular}

Keterangan: Angka-angka yang diikuti huruf yang sama menunjukkan perbedaan yang tidak berbeda nyata (5\%) berdasarkan uji DMRT

Berdasarkan Tabel 3. nilai rerata kuat tarik edible film pada penelitian ini berkisar antara 0,97 $\mathrm{MPa}-2,33 \mathrm{MPa}$. Peningkatan konsentrasi pati singkong menyebabkan kuat tarik edible film akan semakin tinggi. Hal ini dikarenakan penambahan pati yang semakin besar, matriks film yang terbentuk juga akan semakin banyak, sehingga menghasilkan edible film yang kuat. Hal ini sesuai 
dengan pernyataan Warkoyo, dkk (2014) menyatakan penambahan pati yang semakin besar, struktur matriks yang terbentuk akan semakin banyak, struktur matriks film semakin kokoh sehingga kekuatan yang diberikan untuk menyangga beban dari luar semakin besar. Kuat tarik yang semakin besar menunjukan ketahanan terhadap kerusakan akibat peregangan dan tekanan semakin besar, sehingga kualitas fisik yang dihasilkan semakin baik.

\section{Elongasi}

Berdasarkan analisis ragam menunjukkan bahwa tidak ada interaksi antara perbandingan gel okra dan aquades dengan konsentrasi pati singkong terhadap elongasi edible film yang dihasilkan. Demikian juga perbandingan gel okra dan aquades dengan konsentrasi pati singkong tidak berpengaruh nyata terhadap elongasi edible film yang dihasilkan. Rerata nilai elongasi dapat dilihat pada gambar 6 dan 7 .

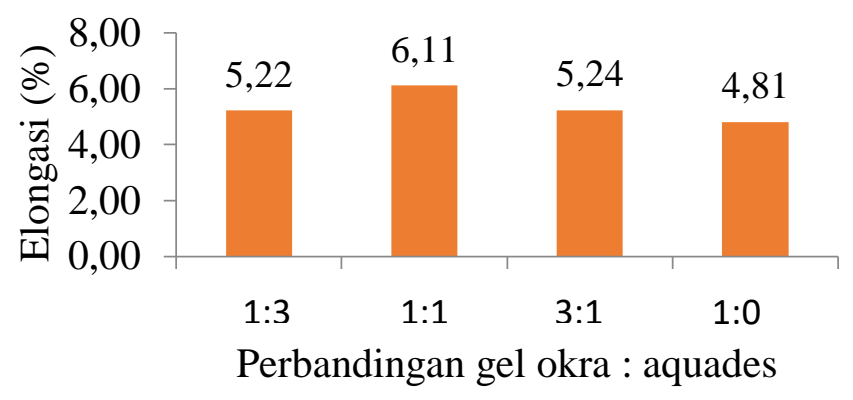

Gambar 6. Histogram Elongasi Edible film terhadap Perbandingan Gel Okra

Berdasarkan Gambar 6. menunjukkan nilai rerata elongasi berkisar antara 4,81\%-6,11\%. Meningkatnya proporsi gel okra akan mengakibatkan penurunan persentasi elongasi edible film. Hal ini dikarenakan gel yang ditambahkan mengisi ruang antar molekul pada struktur polimer edible film yang dapat merapatkan ruang antar molekul sehingga elongasi yang dihasilkan kurang elastis. Menurut Rahim dkk (2010) kenaikan tensile strength juga disertai dengan penurunan nilai elongasi yang menghasilkan film yang kurang elastis dimana nilai elongasi semakin turun dan nilai tensile strength semakin meningkat. Menurut Japanase Industrial Standart (1975) dalam Ariska dkk., (2015) elongasi edible film yang dihasilkan dikategorikan jelek apabila persen pemanjangan edible film kurang dari $10 \%$ dan dikategorikan sangat baik jika persen pemanjangan edible film lebih dari 50\%. Berdasarkan penelitian ini menunjukkan bahwa nilai rata-rata elongasi edible film dengan perbandingan gel okra dan aquades dikategorikan sangat jelek, hal ini dikarenakan nilai dari parameter elongasi yang kurang dari $10 \%$. 


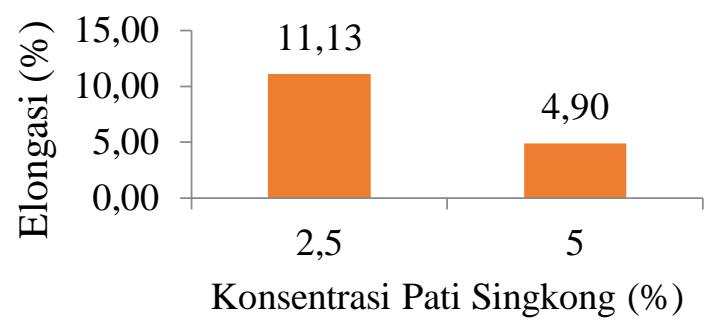

Gambar 7. Histogram Elongasi Edible film Terhadap Konsentrasi Pati singkong

Berdasarkan Gambar 7. dapat diketahui nilai rerata elongasi berkisar antara 4,90\%-11,13\%. Peningkatan konsentrasi pati singkong menurunkan persen elongasi. Hal ini dapat terjadi karena sifat film dipengaruhi oleh komponen penyusun utama dan tambahan edible film, semakin besar pati yang ditambahkan akan menghasilkan pemlastis film yang rendah sehingga menurunkan persen elongasi. Menurunnya persen elongasi ini disebabkan karena pati singkong mengandung kadar amilosa yang cukup tinggi sehingga menjadikan viskositas dan total padatan terlarut juga semakin tinggi yang akhirnya memperkuat ikatan matriks film sehingga mengurangi elongasi edible film yang dihasilkan. Semakin bertambahnya konsentrasi pati singkong pada pembuatan edible film akan menjadikan padatan terlarut dalam film akan semakin banyak, yang mengakibatkan ruang antar polimer akan semakin terisi sehingga mengurangi gerakan molekul polimer yang akhirnya menaikkan suhu transisi gelas (perubahan dari liquid menjadi bentuk solid). Menurut Jacoeb dkk, (2014), apabila suhu transisi gelas meningkat polimer yang terbentuk akan semakin kaku, hal ini akan menyebabkan film tidak fleksibel dan mudah patah saat mengalami peregangan karena itulah nilai elongasi pada penelitian ini lebih rendah (dibawah 10\%).

\section{WVTR (Water Vapor Transmission Rate)}

Berdasarkan analisis ragam menunjukkan bahwa tidak ada interaksi antara perbandingan gel okra dan aquades dengan konsentrasi pati singkong terhadap laju transmisi uap air edible film yang dihasilkan. Perbandingan gel okra dan aquades dengan konsentrasi pati singkung tidak berpengaruh nyata terhadap laju transmisi uap air (WVTR) yang dihasilkan. Rerata nilai laju transmisi uap air dapat dilihat pada gambar 8 dan 9 . 


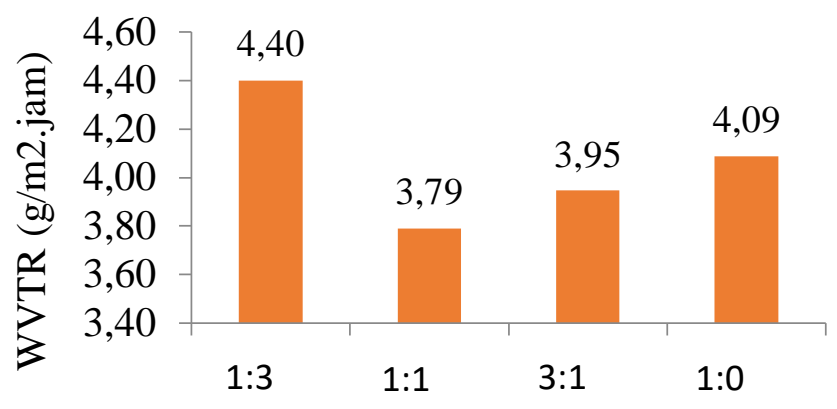

Perbandingan gel okra : aquades

Gambar 8. Histogram Konsentrasi Gel Okra terhadap WVTR Edible film

Berdasarkan Gambar 8. menunjukkan nilai rerata WVTR berkisar antara 3,79 4,40\%-g/m²/24jam. Nilai WVTR meningkat seiring menurunnya proporsi gel okra yang ditambahkan. Hal ini disebabkan karena proposi gel okra yang merupakan komponen penyusun edible film yang ditambahkan rendah sehingga kurang kuatnya menahan air. Menurut Warkoyo dkk., (2014) yang menyatakan bahwa, film dengan komposisi hidrokoloid kurang dalam menahan laju transmisi uap air dikarenakan sifat yang hidrofilik, namun film tersebut dapat mengatur migrasi penguapan air dan barrier yang baik terhadap karbohidrat, lipid dan oksigen. Warkoyo dkk., (2014) juga menambahkan bahwa edible film yang terbentuk dari komponen hidrofilik memiliki kemampuan menahan laju transmisi uap air yang rendah.

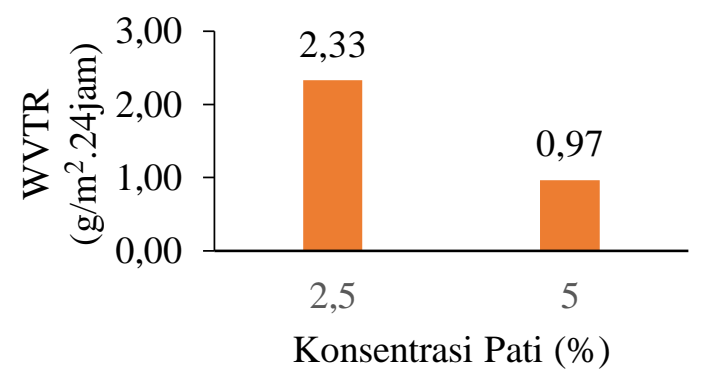

Gambar 9. Histogram WVTR Edible film terhadap Konsentrasi Pati singkong

Berdasarkan Gambar 9. dapat diketahui nilai rerata WVTR berkisar antara $0,97 \%$ - 2,33\%. Meningkatnya konsentrasi pati singkong dalam pembuatan edible film akan cenderung menurunkan transmisi uap air dari edible film yang dihasilkan. Hal ini disebabkan total padatan edible film semakin besar sehingga sedikit peluang air yang masuk dalam film. Menurut Olivato, dkk (2012) menyatakan bahwa penurunan permeabilitas uap air diakibatkan karena berkurangnya gerakan rantai polimer yang mengakibatkan sulitnya difusi air melalui edible film tersebut. Menurut Anandito (2012) tingkat ketebalan akan berpengaruh terhadap kekuatan tarik, elongasi, serta laju transmisi uap air, gas, 
dan senyawa volatile. Semakin tebal, permeabilitas film akan semakin kecil dan jika disesuaikan dengan jenis produk akan menjadi pengemas yang lebih baik.

\section{Perlakuan Terbaik}

Edible film dengan perlakuan terbaik mengacu pada standar edible film yakni JIS (Japanese International Standart). Perlakuan terbaik pada penelitian edible film berbasis gel buah okra dengan penambahan konsentrasi pati singkong adalah perlakuan G2P1 (perbandingan gel okra dan aquades (1:1) dengan konsentrasi pati 2,5\%) dengan menggunakan metode modus dapat dilihat pada table 4.

Tabel 4. Perbandingan Karakteristik Edible Film Terbaik Terhadap Standart JIS

\begin{tabular}{lll}
\hline Parameter & Perlakuan terbaik & JIS \\
\hline Ketebalan & $0,08 \mathrm{~mm}$ & maks. $0,25 \mathrm{~mm}$ \\
Kuat Tarik & $0,74 \mathrm{Mpa}$ & min. $0,39 \mathrm{Mpa}$ \\
Elongasi & $9,24 \%$ & $<10 \%$ sangat buruk \\
& & $>50 \%$ sangat baik \\
WVTR & $3,87 \mathrm{~g} / \mathrm{m} 2 / 24 \mathrm{jam}$ & $7 \mathrm{~g} / \mathrm{m} 2 /$ hari \\
Kelarutan & $23,56 \%$ & - \\
Transparasnsi & $0,58 \mathrm{~A} 546 / \mathrm{mm}$ & - \\
\hline
\end{tabular}

Edible film perlakuan terbaik pada penelitian ini menunjukkan nilai ketebalan, kuat tarik, WVTR sesuai dengan standart JIS. Nilai kelarutan pada perlakuan terbaik G2P1 yaitu 23,56\%, hal ini menunjukkan bahwa edible film tersebut akan mudah dicerna. Pada nilai transparansi perlakuan terbaik yaitu 0,58 A546/mm, hal ini menunjukkan bahwa edible film tersebut transparan/ jernih.

\section{SEM (Scanning Elektron Microscopy)}

Analisis Scanning Electron Mickroscopy plastik edible film dilakukan dengan maksud untuk mengetahui bentuk morfologi plastik yang dihasilkan. Pengujian ini menggunakan alat Scanning Elektron Microscopy dengan tipe bruker. Prinsip kerja SEM yaitu dengan pancaran yang diradiasi terhadap set holder.

Pada Gambar 10 a. dapat dilihat struktur morfologi dari plastik edible film. Permukaan dari plastik edible film perlakuan G2P1 yaitu perbandingan gel okra dan aquades (1:1) dengan 2,5\% pati singkong menunjukkan morfologi dari edible film yang rata dan tidak berongga menunjukkan bahwa terjadi ikatan antar molekul yang kuat antara gel okra dan pati singkong. Hal ini dikarenakan pati memiliki dua macam struktur kimia dimana amilosa merupakan senyawa yang terlarut dan amilopektin merupakan senyawa yang tidak larut. Banyaknya pati 
yang tidak larut (amilopektin) dapat dilihat dari kandungan pati singkong yang memiliki kandungan amilopektin yang lebih banyak dibandingkan dengan amilosa sehingga pada saat pencampuran dan proses pemanasan banyak amilopektin yang tidak larut. Hal ini sesuai dengan literature yang dikemukakan oleh Wulandari (2015) yang menyatakan bahwa amilopektin yang terdapat pada pati lebih banyak daripada amilosa yang terdapat pada pati singkong.

a

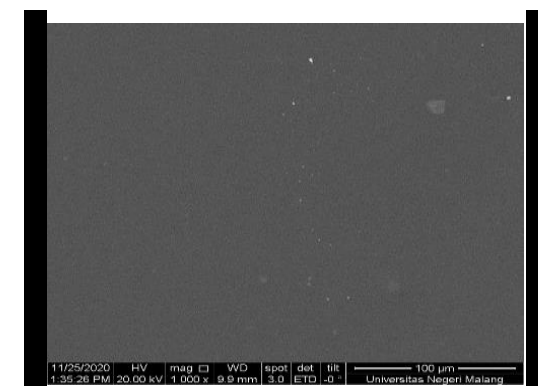

$\mathrm{b}$

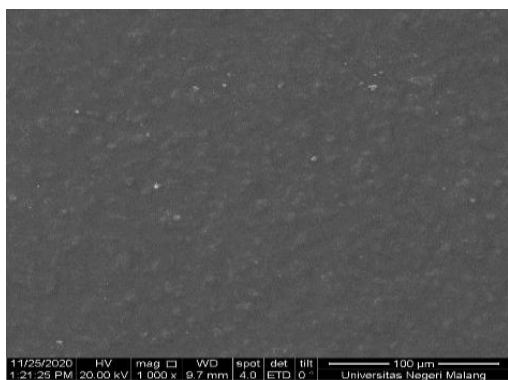

Gambar 10. Hasil analisa Morfologi Edible Film a) Perlakuan Terbaik (G2P1) dan b) Perlakuan Terjelek (G4P2)

Pada Gambar 10 b. Permukaan dari plastik film perlakuan G4P2 yaitu perbandingan gel okra dan aquades (1:0) dengan pati singkong 5\%. Menunjukkan tidak terlalu rata, kurang halus, dan lekukan serta terdapat titik putih pada edible film. Struktur morfologi yang tidak rata disebabkan oleh pengadukan yang kurang homogen pada saat pemanasan gel okra dan pati singkong. Ketidakberaturan permukaan plastik edible film tersebut disebabkan oleh adanya makromolekul dalam plastik yang dihasilkan seperti pati, lemak serta protein yang terkandung di dalam polimer plastik. Hal ini sesuai dengan penelitian sebelumnya yang dilakukan oleh Kumoro, dkk (2014) yang meneliti tentang sifat mekanik dan morfologi plastik biodegradable yang menghasilkan struktur morfologi plastik yang tidak beraturan yang disebabkan oleh kandungan makromolekul dalam plastik.

\section{KESIMPULAN}

Berdasarkan hasil penelitian yang sudah dilakukan, maka dapat disimpulkan bahwa perbandingan gel okra dan aquades dengan konsentrasi pati singkong terhadap ketebalan, transparasi, kelarutan, elongasi, WVTR dan kuat Tarik.Perbandingan gel okra dan aquades berpengaruh nyata terhadap uji transparasi Dan konsentrasi pati singkong berpengaruh nyata terhadap uji transparasi dan kuat Tarik. Edible film dengan perlakuan terbaik didapat pada perlakuan G2P1 perbandingan gel okra dan aquades (1:1) dengan konsentrasi pati singkong $2,5 \%$. 


\section{REFERENSI}

Al-Hasan, A.A. dan Norziah, M.H. 2012. Starch Gelatin Edible films:Water Wapor Permeability and Mechanical Properties As Affected by Plasticizers. Food Hydrocolloids 26: 108-117. url: https://doi.org/10.1016/j.foodhyd.2011.04.015

Anandito, RB., K. Nurhartadi dan E, Bukhori. A,. 2012. Pengaruh gliserol terhadap karakteristik edible film berbahan dasar tepung jali (Coix lacrymajobi L.). Jurnal Teknologi Hasil Pertanian. V(2).

Ariska RE, Suyatno. 2015. Pengaruh konsentrasi karagenan terhadap sifat fisik dan mekanik edible film dari pati bonggol pisang dan karagenan dengan plasticizer gliserol. Prosiding. Seminar Nasional Kimia Jurusan Kimia FMIPA Universitas Negeri Surabaya. Surabaya.

Bao, S., Xu, S. dan Wang, Z. 2009. Antioxidant activity and properties of gelatin flms incorporated with teapolyphenol-loaded chitosan nanoparticles. Journal of the Science of Food and Agriculture 89: 2692-2700

Fitria, E.N., 2014. Pengaruh Penambahan CMC (Carboxy Methyl Cellulose) Dan Sorbitol Terhadap Karakteristik Fisik, Mekanik Dan Barrier Edible film Gel Okra (Abelmoschus Esculentus L.). Skripsi. Universitas Muhammadiyah Malang, Malang

Hidayat, C. 2009. Peluang Penggunaan Kulit Singkong Sebagai Pakan Unggas. Wartazoa,23 (1): 15-22.

JIS ( Japanesse Industrial Standard ) 2 1707.1975. General Rules of Plastic Film for FoodPackaging. Japanesse Standards Association. Tokyo : JSA.

Krochta, J. M., Baldwin, E. A., dan M., O. Nisperos-Carriedo, 1994, Edible coatings and film to improve food quality, Economic Publ. Co. Inc., USA.

Kumoro, A.C., P. Aprilina. 2014. Sifat Mekanik dan Morfologi Plastik Biodegradable Dari Limbah Tepung Nasi Aking dan Tepung Tapioka Menggunakan Pemlastik Gliserol. Jurnal. Jurusan Teknik Kimia. 35 (1): 816, https://doi.org/10.14710/teknik.v35i1.6238

Lim. V, Kardono, L. B. S, Kam, N. 2015. Studi Karakteristik dan Stabilitas Pengemulsi Dari Bubuk Lendir Okra (Abelmoschus esculentus). Jurnal Aplikasi Teknologi Pangan 4 (3): 135

Misnawati. 2015. Studi Pembuatan Edible film Dari Proporsi Karagenan Kitosan Dan Penambahan Larutan Pati Kimpul. Skripsi. Universitas Muhammadiyah Malang. Malang.

Mustafa, A. 2015. Proses Pembuatan Ubi Kayu (Tapioka) berbasis Neraca Massa. AGROINTEK, Volume 9 No.2

Nurindra, A. P., Alamsjah, M. A., Sudarmo. 2015. Karakterisasi Edible film dari Pati Propagul Mangrove Lindur (Bruguiera gymnorrhiza) dengan Penambahan Carboxymethyl Cellulose (CMC) sebagai Pemlastis. Jurnal Ilmiah Perikanan dan Kelautan. 2(7): 129 
Pratiwi, K. I, Zaini, M. A, Nazaruddin. 2016. Pengaruh Konsentrasi Gel Buah Okra (Abelmoschus esculentus L.) terhadap Mutu Es Krim Campuran Susu Sapi Dan Susu Kedelai. Pro Food (Jurnal Ilmu dan Teknologi Pangan). 2(2) : 2443-1095

Rahim, A., Alam, N. 2010. Pengaruh Konsentrasi Pati Aren dan Minyak Sawit terhadap Sifat Fisik dan Mekanik Edibel Film. Jurnal Agroland 17 (1), 3846

Sani, R.N., Fithri C.N., Ria D.A., dan Jaya M.M. 2014. Analisis Rendemen dan Skrining Fitokimia Ekstrak Etanol Mikroalga Laut Tetraselmis chuii. Jurnal Pangan dan Agroindustri.2 (2) : 121 -126

Warkoyo, Rahardjo, B., Marseno, D. W., \& Karyadi, J. N. W. 2014. Sifat Fisik, Mekanik dan Barrier Edible Film Berbasis Pati Umbi Kimpul (Xanthosoma sagittifolium) yang Diinkorporasi dengan Kalium Sorbat. Agritech 34(1), $72-81$

Wulandari, Y.D 2015. Studi Pembuatan Edible film Berbasis Pektin Kulit Pisang Candi (Musa Paradisiaca Linn) Dengan Penambahan Tepung Tapioka Yang Diaplikasikan Pada Dodol. Skripsi. Universitas Muhammadiyah Malang, Malang.

Yuniarifin, H, Bintoro VP, Suwarastuti A. 2006. Pengaruh Berbagai Konsentrasi Asam Fosfat pada Proses Perendaman Tulang Sapi terhadap Rendemen, Kadar Abu dan Viskositas Gelatin. Journal Indon Trop Anim Agric. 31(1) : 55- 61 